\title{
KARYOTYPE CHARACTERIZATION OF Malpighia emarginata (MALPIGHIACEAE) ${ }^{1}$
}

\author{
MATEUS MONDIN ${ }^{2}$, CARLOS ALBERTO DE OLIVEIRA ${ }^{3}$, MARIA LÚCIA CARNEIRO VIEIRA $^{4}$
}

ABSTRACT - Malpighia emarginata Sessé \& Mociño ex DC. or West Indian cherry (acerola) is a wild plant originated in southern Mexico, Central America and the northern region of South America. The species was introduced to Brazil about 60 years ago and now the country is the world's biggest producer. Even though the fruits of acerola have high commercial value, as they are an important source of the natural vitamin C, very little chromosome information is available for this species. Previous studies showed that most Malpighia species are diploids, including M. emarginata with $2 \mathrm{n}=20$. In the present paper, the chromosome number of acerola was confirmed, and for the first time, its karyotype was described, providing the identification of the homologues for the ideogram construction. The acerola chromosomes are small (1.71 to $2.56 \mu \mathrm{m}$ ) and metacentric with the exception of chromosome 2 that was classified as submetacentric. In addition, it is recommended a protocol to produce rooted-plantlets in vitro for mitotic studies that could be also used for micropropagation of acerola.

Index terms: acerola, cytology, chromosomes, in vitro culture establishment, West Indian cherry.

\section{CARACTERIZAÇÃO CARIOTÍPICA DE Malpighia emarginata (MALPIGHIACEAE)}

RESUMO - Malpighia emarginata Sessé e Mociño ex DC., ou acerola, é uma planta silvestre originada do sul do México, América Central e região norte da América do Sul. A espécie foi introduzida no Brasil há cerca de 60 anos e o País é o maior produtor mundial. Embora os frutos da acerola tenham alto valor comercial, pois são uma importante fonte natural de vitamina $\mathrm{C}$, pouco se conhece sobre os cromossomos da espécie. Estudos prévios mostraram que a maioria das espécies de Malpighia é diploide, incluindo M. emarginata $\operatorname{com} 2 n=20$. No presente trabalho, foi confirmado o número cromossômico da acerola e foi descrito, pela primeira vez, o seu cariótipo, provendo a identificação dos homólogos para a construção do ideograma. Os cromossomos da acerola são pequenos $(1,71$ a $2,56 \mu \mathrm{m})$ e metacêntricos, com exceção do cromossomo 2 , que foi classificado como submetacêntrico. Além disso, definiu-se um protocolo para produzir plântulas enraizadas in vitro para estudos mitóticos, o qual pode, igualmente, ser usado para a micropropagação da acerola. Termos para indexação: acerola, citologia, cromossomos, estabelecimento in vitro, West Indian cherry.

\section{INTRODUCTION}

Malpighia emarginata Sessé \& Mociño ex DC. is a wild plant originated in southern Mexico, Central America and the northern region of South America where it occurs as a shrub of approximately $6 \mathrm{~m}$ high. Originally, botanists classified the Barbados cherry as Malpighia glabra and the West Indian cherry as $M$. punicifolia while others proposed that M. emarginata might result from hybridization between these species. In 1986, the International Board of Plant Genetic Resources (IBPGR) stated that Malpighia emarginata is the correct name for the West Indian cherry (acerola) and rejected the use of M. glabra as a synonym.
Acerola has drupaceous fruits with a soft yellow and acid pulp, and three imbricate flattened seeds. Remarkably, they present a high ascorbic acid content (0.69-4.82 g /100 g of pulp), being an important commercial source of natural vitamin $\mathrm{C}$. Fruits also present carotenoids and bioflavonoids that possess important nutritive value and make it potentially useful as an antioxidant (see MEZADRI et al., 2006). Acerola plant is often cultivated as an ornamental shrub, particularly in the southeastern of United States.

The crop is increasingly cultivated in South America, mostly in Brazil that is the main producer, where it was introduced 60 years ago. Studies suggest

\footnotetext{
(Manuscript 128-09) Received in : 25-05-2009. Accepted for publication in : 23-10-2009.

${ }^{2}$ Agronomic Engineer, Dr., Assistant Professor, University of Sao Paulo, Escola Superior de Agricultura "Luiz de Queiroz", 13400900, Piracicaba, Brazil.

${ }^{3}$ Biologist, Laboratory Technician, University of Sao Paulo, Escola Superior de Agricultura “Luiz de Queiroz”, 13400-900, Piracicaba, Brazil.

${ }^{4}$ Biologist, Dr., Professor in Plant Genetics, University of Sao Paulo, Escola Superior de Agricultura “Luiz de Queiroz”, 13400-900, Piracicaba, Brazil. To whom correspondence should be addressed. E-mail: mlcvieir@esalq.usp.br
} 
that acerola is an allogamous species that developed the specific adaptations needed for plant growth in tropical and subtropical Brazilian regions. Despite its narrow genetic basis, the introduced genotypes present high variability in morphological and quantitative characters as well as for resistance to Meloidogyne incognita (LOPES et al., 2002; ROSSITER et al., 2008).

Even though the fruits of acerola have high commercial value, very little chromosome information is available on the species. Previous studies showed that most Malpighia species are diploids, including $M$. emarginata, with $2 \mathrm{n}=2 \mathrm{x}=20$ while some are tetraploids (LOMBELLO; FORNI-MARTINS 2003). In the present paper, the karyotype for this species is described providing the identification of the homologues and chromosome arrangements for ideogram construction. In addition, it is recommended a protocol to produce healthy rootedplantlets for mitotic studies that could be also used for micropropagation of acerola.

\section{MATERIAL AND METHODS}

\section{In vitro culture establishment}

Acerola seeds were separated by washing them in tap water before being air-dried and planted in a mixture of soil, sand and humus (1:1:1). When the seedlings were $4 \mathrm{~cm}$ long, apical shoots were excised, washed thoroughly for $30 \mathrm{~min}$, then sterilized in $70 \%$ ethanol for 40 s and in a $2 \%$ sodium hypochlorite (v/v) solution plus $0.1 \%$ Movadol (v/v) (47.5\% benzalkonium chloride, $37 \%$ formaldehyde) for $1 \mathrm{~min}$. The sterilized apical shoots were inoculated in MS medium (MURASHIGE; SKOOG, 1962) containing half of the original concentration of salts and vitamins, $30 \mathrm{~g} \mathrm{dm}^{-3}$ sucrose, devoid of plant hormones $(1 / 2 \mathrm{MS})$. After 20 days, the cultures were transferred to the same basal medium supplemented with $0.4 \mathrm{mg} \mathrm{dm}^{-3}$ of IBA (3-indolbutyric acid) for root inducing. One week later, all the cultures were transferred to $1 / 2 \mathrm{MS}$.

\section{Karyotype analysis}

Root tips were collected from in vitro-grown apical shoots, pre-treated with $0.1 \%$ colchicine $(\mathrm{w} / \mathrm{v})$ for $2 \mathrm{~h} 50 \mathrm{~min}$, and fixed in ethanol-acetic acid (3:1). The conventional Feulgen staining procedure was used. For karyomorphological studies, metaphases were rigorously selected based on the level of chromosome condensation. Slides were photographed using an Olympus photomicroscope (BX50) and Ilford black-and-white film 50 ASA. Chromosome measurements were performed on 10 magnified microphotographs $(3,600 \mathrm{X})$. Means of the absolute lengths, relative lengths (expressed as percentage of haploid set) and arm ratios were calculated for identifying the chromosome pairs and for drawing the ideogram. Centromere positions were designated according to Guerra (1986).

\section{RESULTS}

The seeds germinated 20 days after planting, but only $30 \%$ of them developed into normal seedlings. Therefore, when plantlets were $4 \mathrm{~cm}$ long and had 3-4 leaves, apical shoots were excised for in vitro cultivation. No contamination was detected during the culture period. Some of the plantlets (ca. 10\%) were discarded as stems and leaves became pale and chlorotic. The remaining plantlets developed roots 10 days after the transference from $1 / 2$ MS plus $0.4 \mathrm{mg}$ $1^{-1}$ of IBA to $1 / 2 \mathrm{MS}$ (Figure 1A). Even when the root tips were harvested for cytological analyses, plantlets developed new roots (Figure 1B).

The karyotype and the ideogram of M. emarginata are shown in Figure 2. We observed $2 n=20$ chromosomes, which were classified according to their lengths and centromere positions (Table 1). The chromosome pairs were numbered 1 to 10 , chromosome 1 being the largest $(2.56 \mu \mathrm{m})$ and chromosome 10 the shortest $(1.71 \mu \mathrm{m})$. Except for chromosome 2 that was submetacentric (arm ration $=1.65)$, all chromosomes of the haploid set were classified as metacentric, their arm ratios ranging from 1.22 (chromosome 7) to 1.40 (chromosome 4). The submetacentric characteristic of chromosome 2 is clearly shown in Figure 2A. In every metaphase plate, only primary constrictions (centromeres) were observed. Secondary constrictions or satellite-like structures were not identified. The haploid set has $21.05 \mu \mathrm{m}$.

\section{DISCUSSION}

The chromosome number has been reported for at least $10 \%$ of species of the Malpighiaceae, and $x=10$ appear to be the basic number for the family. The genus Malpighia belongs to the sub-family Malpighioideae, tribe Hiptageae. According to Lombello $\&$ Forni-Martins (2003), the diploid number $2 n=20$ represents $42.2 \%$ of the chromosome counts of $\mathrm{Mal}$ pighioideae, the remaining ones being tetraploid $(2 \mathrm{n}=$ $4 x=40$ ). The possibility of an ancient $x=5$ for the Malpighioideae species was also mentioned by these authors. Polyploidy was suggested by several authors to play an important role in directing Malpighiaceae chromosome evolution, and paleopolyploidy origin 
could not be discarded.

In the present work, individual chromosomes were distinguished based on careful measurements of their total length, relative length and arm ratio. The karyotype and ideogram were established for M. emarginata (Figure 2C). With the exception of chromosome 2, all acerola chromosomes were small and metacentrics. Our results are in accordance with Lombello (2000) that studied 23 species of 12 genera of Brazilian Malpighiaceae, most of the species showing relatively small chromosomes $(1.1 \mu \mathrm{m}$ to $3.9 \mu \mathrm{m})$, predominantly metacentrics.

Most chromosome measurements showed standard deviations lower than $10 \%$ as expected for high-quality metaphase plates. However, for the arm ratio of chromosome 2 , the standard deviation was $16 \%(1.65 \pm 0.27)$. It was suspected that this deviation cannot be attributed to random variation as reported in Hypericum perforatum (BRUTOVSKÁ et al., 2000). Probably, a centromeric shift had occurred in chromosome 2. It alters the position of the centromeres but does not alter the linear order of the genes (FERRERI et al., 2005). Several hypotheses were proposed to explain centromere permutability or repositioning within a chromosome. This event is not exceptional and must be considered when examining chromosome structure (reviewed by FERRERI et al., 2005, LAMB et al., 2007, MA et al., 2007).

A combination of pre-treatment duration, concentration of spindle inhibitor and level of chromosome contraction are crucial for obtaining highquality metaphase preparations for measurements. Our group has used this strategy to determine the karyotype of Stylosanthes (VIEIRA et al., 1993) and Passiflora species (CUCO et al., 2005) as well as for Crotalaria juncea (MONDIN et al., 2007). For this reason, we may speculate here that the variation observed in chromosome 2 is due to a shift of the centromere segment.
Interestingly, neither secondary constrictions nor satellites were found in M. emarginata. Satellite identification in metaphase chromosomes results from active nucleolar-organizing regions (NORs) during early interphase. Cells have at least one active NOR, even though satellites are not visualized. Two kinds of events could explain the non-observation of satellites in metaphase chromosomes: the satellites are in the telomeric region or the expression of nucleolar-organizing regions is not sufficient to result in secondary constriction or satellite formation. In Crotalaria juncea, for instance, Mondin et al. (2007) showed that a NOR site was positive but no secondary constriction was visualized at metaphase, the chromosome morphology remaining unmodified.

One problem pointed out by agronomists in relation to acerola cultivation is the high heterogeneity of the trees that differ in their plant habits, fruit sets and fruiting habits, generating low-producing orchards and fruits of low quality for commercialization. Moreover, acerola seeds have very low frequencies of germination, mainly due to the occurrence of problems during embryo formation (COSTA et al., 2003). In addition, plants derived from seeds segregate and experience a long juvenile period before production. A solution to these problems is asexual propagation through cutting, grafting, and in vitro culture. In this case, we should consider the use of mature plants as donors of explants e.g. apical shoots for in vitro propagation of acerola and preservation of $M$. emarginata germplasm. Here we used this approach to produce healthy rootedplantlets without having any damage in the root tips for mitotic studies. 

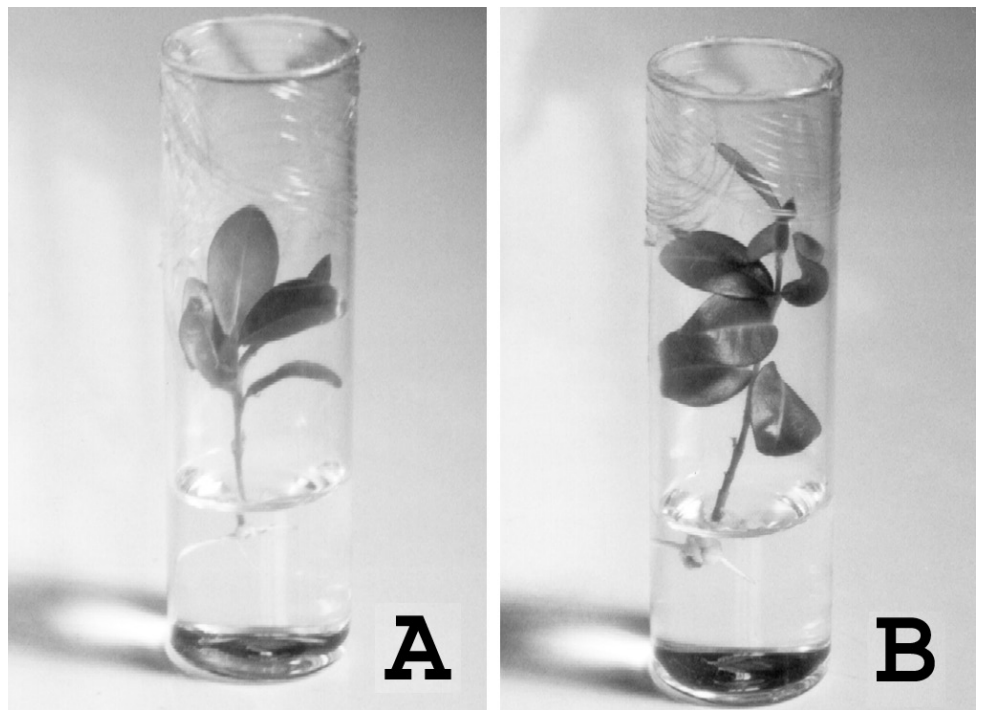

FIGURE 1 - In vitro propagation of Malpighia emarginata (A). Note the development of new roots after harvesting the first root tips for cytological analysis (B).

\section{Hด}

A
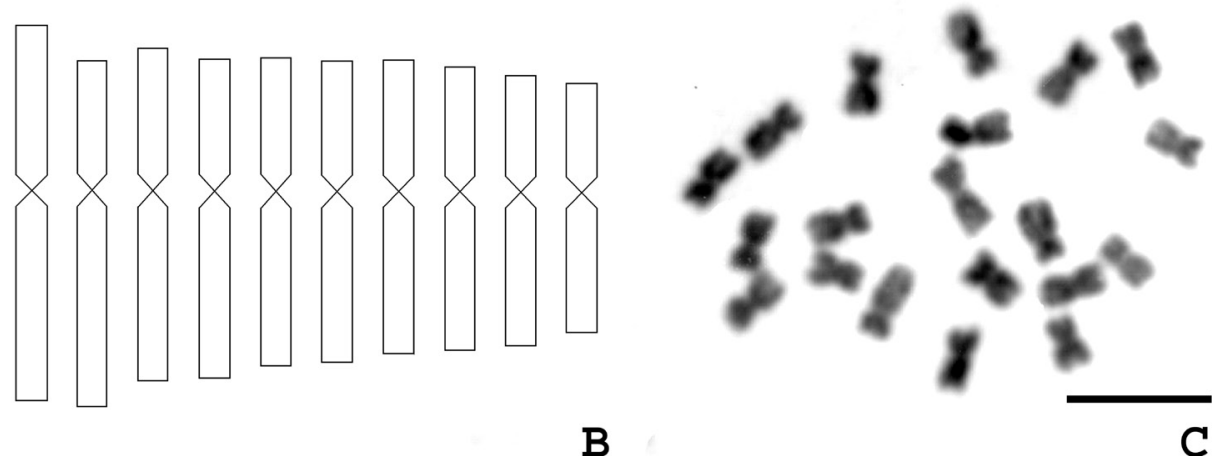

B

C

FIGURE 2 - Karyotype of Malpighia emarginata (A). Ideogram established based on the mean measurements of the chromosomes (B). A mitotic metaphase plate showing $2 \mathrm{n}=20(\mathrm{C})$. Bar $=5 \mu \mathrm{m}$. 


\section{CONCLUSION}

1-M. emarginata is a diploid species $(2 \mathrm{n}=$ 20) with small (1.71 to $2.56 \mu \mathrm{m})$ and metacentric chromosomes, with the exception of chromosome 2 that is submetacentric. The haploid set has $21.05 \mu \mathrm{m}$.

2-The protocol for producing healthy rootedplantlets for mitotic studies could be also used for micropropagation of acerola through apical shoots. In vitro cultures may be established in half-strength MS medium supplemented with $0.4 \mathrm{mg} \mathrm{l}^{-1}$ of IBA for 10 days followed by transfer to hormone-free half-strength MS.

\section{ACKNOWLEDGMENTS}

The authors thank the Brazilian Instituition $\mathrm{CNPq}$, for financial support. $\mathrm{MM}$ received a PRODOC / CAPES Fellowship. Christopher Burden is acknowledged for proofreading of the manuscript.

\section{REFERENCES}

BRUTOVSKÁ, R.; KUSNIRIKOVÁ, P.; BOGYIOVÁ, E.; CELLÁROVÁ, E. Karyotype analysis of Hypericum perforatum L. Biologia Plantarum, Prague, v.43, n.1, p.133-136, 2000.

COSTA, L.C.; PAVANI, M.C.M.D.; MORO, F.V.; PERECIN, D. Viabilidade de sementes de acerola (Malpighia emarginata DC): avaliação da vitalidade dos tecidos. Revista Brasileira de Fruticultura, Jaboticabal, v.25, n.3, p.532-534, 2003.

CUCO, S.M.; VIEIRA, M.L.C.; MONDIN, M.; AGUIAR-PERECIN, M.L.R. Comparative karyotype analysis of three Passiflora L. species and cytogenetic characterization of somatic hybrids. Caryologia, Firenze, v.58, n.3, p.220-228, 2005.

FERRERI, G.C.; LISCINSKY, D.M.; MACK, J.A.; ELDRIDGE, M.D.B.; O'NEILL, R.J. Retention of latent centromeres in mammalian genome. Journal Heredity, Oxford, v.96, p.217-224, 2005.

GUERRA, M.S. Reviewing the chromosome nomenclature of Levan et al. Revista Brasileira de Genética, Ribeirão Preto, v.9, n.4, p.741-743, 1986. 
LAMB, J.C.; MEYER, J.M.; BIRCHLER, J.A. A hemicentric inversion in the maize line knobless Tama flint created two sites of centromeric elements and moved the kinetochore-forming region. Chromosoma, Heidelberg, v.116, n.3, p.237-247, 2007.

\section{LOMBELLO, R.A. Estudos cromossômicos em}

Malpighiaceae A. Jussieu. 2000. Tese (Doutorado em Biologia Vegetal) - Instituto de Biologia, Universidade Estadual de Campinas, Campinas, 2000.

LOMBELLO, R.A.; FORNI-MARTINS, E.R. Malpighiaceae: correlations between habit, fruit type and basic chromosome number. Acta Botanica Brasilica, São Paulo, v.17, n.2, p.171-178, 2003.

LOPES, R.; BRUCKNER, C.H.; LOPES, M.T.G. Estimação da taxa de cruzamento da aceroleira com base em dados isoenzimáticos. Pesquisa Agropecuária Brasileira, Brasília, v.37, n.3, p.321-327, 2002.

MA, J.; WING, R.A.; BENNETZEN, J.L.; JACKSON, S.A. Plant centromere organization: a dynamic structure with conserved functions. Trends in Genetics, Amsterdam, v.23, n.3, p.134-139, 2007.

MEZADRI, T.; FERNÁNDEZ-PACHÓN, M.S.; VILLAÑO, D.; GARCÍA-PARRILLA, M.C.; TRONCOSO, A.M. El fruto de la acerola: composición y posibles usos alimenticios. Archivos Latinoamericanos Nutrición, Caracas, v.56, n.2, p.101-109, 2006.
MONDIN, M.; SANTOS-SEREJO, J.A.; AGUIARPERECIN, M.L.R. Karyotype characterization of Crotalaria juncea (L.) by chromosome banding and physical mapping of $18 \mathrm{~S}-5.8 \mathrm{~S}-26 \mathrm{~S}$ and $5 \mathrm{~S}$ rRNA gene sites. Genetics Molecular Biology, Ribeirão Preto, v.30, n.1, p.65-72, 2007.

MURASHIGE, T.; SKOOG, F. A revised medium for rapid growth and bioassays with tobacco tissue cultures. Physiologia Plantarum, Copenhagem, v.15, n.3, p.473-497, 1962.

ROSSITER, J.G.A.; MUSSER, R.S.; MARTINS, L.S.S.; PEDROSA, E.M.R.; MEDEIROS, J.E. Seleção de genótipos de aceroleira assistida por marcadores isoenzimáticos visando à resistência a Meloidogyne incognita Raça 2. Revista Brasileira de Fruticultura, Jaboticabal, v.30, n.4, p.10571064, 2008

VIEIRA, M.L.C.; MARTINS, P.S.; AGUIARPERECIN, M.L.R. A cytotaxonomic study in twelve Brazilian taxa of Stylosanthes Sw., Leguminosae. Cytologia, Tokyo, v.58, n.3, p.305-311, 1993. 